UDC 551.24(574)

P.V. Yermolov', Acad. of NAS of RK,
Dr. Sc. (Geol.-Min.), Prof.,
orcid.org/0000-0002-9635-8634,
Ye. V. Ponomareva'2,
orcid.org/0000-0003-1322-6773,
V.S. Portnov ${ }^{2}$, Dr. Sc. (Tech.), Prof.,
orcid.org/0000-0002-4940-3156

\section{AGE AND GEODYNAMICS OF THE IRTYSH SHEAR ZONE}

Purpose. Studying the age and structural relationships of the Irtysh shear zone with the Kalba-Narym zone, determining the age and geodynamic position of crystalline rocks at high temperatures and moderate pressures of the Irtysh shear zone.

Methodology. Analysis of literature and stock materials; field research; sample preparation; carrying out isotope studies using SHRIMP-2 and LA-ICP-MS technology; determining small elements by the fusion method using ICP.

Findings. Detailed geological, petrographic and geochemical studies made it possible to identify three independent metamorphic complexes of the Irtysh shear zone, to determine their age and to establish the geodynamic position of the complexes of the Irtysh shear zone.

Originality. The age of the main magmatic and metamorphic complexes developed in the central part of the Irtysh shear zone has been determined; SHRIMP-II, LA-ICP-MS technologies of foreign laboratories have been used; by the results of new dating the geodynamics of the Irtysh shear zone has been corrected.

Practical value. From the standpoint of accretion tectonics, using up-to-date isotope dating methods, an attempt has been made to consider the geodynamics of crustal geoblocks ("terrains") and to find continuation of ore levels and ore belts of some terrains in the other ones.

Keywords: isotope dating, geodynamic position, metamorphic rocks, granite-gneiss, schists, zircon, the Irtysh shear zone

Introduction. In understanding the geological geodynamics and geodynamic position of the South-West (specifically Kalba-Narym) part of the terrain geologists have no principal discords today. As to the north-east part, which was distinguished by a lot of geologists as the Irtysh structural-formation zone (the Irtysh horst, the Irtysh Benioff zone), there is a number of unsolved problems and we will distinguish three of them: the first one is whether the Irtysh shear zone is a component of the unified Kalba-Narym terrain or an independent formation; the second one concerns the age of the metamorphic rocks making about $85 \%$ of the Irtysh shear zone; the third one is the age and the shear amplitude that separates the Irtysh shear zone from the Rudny Altai.

Analysis of the recent research and publications. In the hundred-year history of studying the Irtysh zone there can be identified four major time stages:

1925-1958. Two models were developed and co-existed: the late Hercynian shear zone formed as a result of shear deformations in the Middle and Late Paleozoic rocks (Nekhoroshev) and the tectonic zone of the faultshear character, along which the crystalline rocks of the old basement were removed to the upper level (Yeliseyev).

1958-1973. In these years the two models developed further (Ivankin, Kuzebny, Gavrilova, Khoreva, and others). In the first model massive molten dating of mica with potassium-argon method were cited, and the second included the ancient lead-isochronous dating of marbles in the composition of gneiss-shaly strata.

(C) Yermolov P. V., Ponomareva Ye. V., Portnov V. S., 2018
1975-1997. Based on the uranium-lead dating of using discordant models, it became possible to determine the formation of zircon in the gneisses and migmatites, which fluctuated in the range of 1450-1800 million years, and the time of the last closing of the system 462-305 million years (Naydenov, Yermolov, Polyansk, Bespayev, et al.). The youngest events in recent years are detailed in the work (Travin A.V., Ponomarchuk V. A., Ponomareva A. P., et al.), in which there are two intervals: $276-283$ and $265-272$ million years, corresponding, in the authors' opinion, to viscous-plastic deformations arising during introducing the KalbaNarym batholith and complex ongonitic dikes crossing both batholith and the metamorphic complex of the Irtysh shear zone.

2005-2013. In modern isotopic centers of Russia and China, it is the period of the use of methods of local isotope-geochronological dating. Within this period it became possible to establish for the first time the presence in the structure of the Irtysh shear zone of ancient metamorphic complexes as a result of the studies. In 2007, in the Chinese part of the zone in the vicinity of the FuYun village there were revealed gneiss granites and tonalite gneisses of the Late-Ordovician age [1,2]. A year later P. Yermolov published the data of the Cambrian age of the protolith metamorphic complexes in the middle and south-eastern parts of the Irtysh shear zone [3]. Moreover, it was found that the rocks were subjected to regional metamorphism in Ordovician and the late Silur and subsequent activation in the Perm. Massive megablocks of gneisses, such as Kurchumsky, did not experience such activation [3]. Later these data were 
confirmed $[4,5]$. The uranium-lead dating of the collective [6] is mainly emphasized on the Middle Paleozoic history of the Irtysh zone in the age range of 338-320 Ma.

Unsolved aspects of the problem. The problem of metamorphism for geology of the zone under consideration is the key one and largely determines interpretation of the tectonic structure and development, the regularities of manifestation of magmatism and metallogeny. Beginning with the earliest descriptions of metamorphic rocks in this zone and up to the present time their age and genesis are constantly debated. There are dominant ideas about the dynamic-thermal transformation of enclosing rocks with participation of granitoids and gabbroids intrusions that have penetrated the shear zone.

The age of the rocks along which the crystalline schists formed in the Upper Paleozoic was first identified as the Cambrian-Silurian, but later they were broken up into several suites with the age from the middle Devonian to the Lower Carboniferous. Alongside with this, it was pointed out that the metamorphic rocks also belong to the protuberances of the ancient crystalline basement. On the basis of the new data obtained, as well as the analysis of previous materials, a number of contradictions have been revealed that cannot be satisfactorily explained from the standpoint of the young age of regional metamorphism. The main contradiction lies in the fact that the intrusions lying in the Irtysh zone have an early-stone age, and the metamorphic rocks are the Cambrian and Ordovician rocks. The introducing of the Kalba batholith occurred in the early Perm, when the Irtysh zone was completely formed.

In the understanding of the geology and geodynamic position of the southwest (actually Kalba-Narym) part of the terrain geologists have no principle discords today. As for the northeastern part that was distinguished by many geologists earlier in the Irtysh structural and formational zone (the Irtysh horst, the Irtysh Benioff zone), there are unresolved problems, of which there are distinguished three main ones:

1) whether the Irtysh zone is an integral part of the single Kalba-Narym terrain or an independent terrain;

2) the age of metamorphic rocks composing about $85 \%$ of the Irtysh shear zone;

3) the age and the shear amplitude separating the Irtysh shear zone from the Rudny Altai.

Objectives of the article. Studying the age and structural relationships of the Irtysh shear zone with the Kalba-Narym zone, determining the age and geodynamic position of crystalline rocks at high temperatures and moderate pressures of the Irtysh shear zone.

Description of methods for carrying out the study. In 2014-2015 for identifying zircon there were taken 5 samples on the right and left banks of the Ulba River and 25 samples for determining the chemical composition and studying the rare earth mineralization. Polished sections and polishes were made of them. Sampling points are shown in Fig. 1. For all the samples there were obtained the results of analyses using the SRIMP-2 technology ( $\mathrm{U} / \mathrm{Pb}$ age) on the microprobe
JEOL-733 (mineral composition), the quantitative analysis for the REE by the fusion method with decoding by the method of ICP-OES. Preparing polished sections, description and photographing were carried out on the equipment of the Zeiss Company.

Presentation of the main research and explanation of scientific results. According to geophysical data, the Irtysh shear zone (ISZ) is traced to the depth of more than $100 \mathrm{~km}$ as a steeply falling structure. The total outstretch of the zone is $285-320^{\circ}$, the width is $10-50 \mathrm{~km}$. The shear zone was formed in connection with the long tectonic life of the Irtysh deep seam of the sub-crust deposit, the main disjunctivities of which are the Irtysh and Kalba-Narymsky faults. The general structure of the ISZ is a stepwise asymmetric linear horst-anticlinorium in the Axis subzone with differently constructed North-Eastern and South-West subzones, Fig. 2.

The tectonic position of the Irtysh zone is not unambiguously assessed. V. P. Nekhoroshev distinguished two structural-facies zones in the region: the Rudny Altai and Kalba-Narym, and the Irtysh shear zone in the latter. In the 60-70-s of the last century the team of geologists of the IGS n.a. K. I. Satpayev and the Altai geological survey expedition identified it on the principles of the geosynclinal concept as an independent structural-facies zone.

The new concept of plate tectonic that became widespread in Kazakhstan since the end of the $20^{\text {th }}$ century, gave a fundamentally different explanation of the genesis of the former structural-facies zones and operated geoblocks of the earth crust that received the name of terrains. From the standpoint of plate tectonics, only the Rudny Altai and Kalba-Narym geoblocks can serve as independent terrains, and the Irtysh crush zone that, on the whole, has a scaly structure, is a collection of many small, uneven-aged blocks assembled into a structure of the tectonic horst type due to accretion (conglomeration). Metasediment rocks strictly predominate in the Irtysh shear zone, therefore its belonging to the KalbaNarym terrain that is also composed of pre-material sedimentary rocks, becomes more correct than belonging to the Rudny Altai terrain.

The ISZ position in geological structures of the region is shown in Fig. 2. In the northeast it is limited by the Main Irtysh fault, which is manifested in the form of a clear tectonic seam. In the south-west the border of the Kalba-Narym terrain goes along the Terektinsky fault, which in most of the territory is blocked by early Carboniferous sediments, but clearly expressed as the edge of the Kalbin batholith.

In the structure of the Irtysh zone there dominate metamorphic complexes of high and moderate pressures in the range of temperature facies from the lower greenschist to high-temperature amphibolite with the signs of presence of relic parageneses of the granulite facies in the latter. These metamorphic complexes have an age range from the Precambrian to the Devon and their share in the structure of the Irtysh zone reaches 90-95\%.

In the ISZ structure three real-structural complexes are distinguished (Fig. 1, $b$ ): the first one is the complex of high temperatures and low pressures; the second one is the complex of high pressures and moderate tempera- 


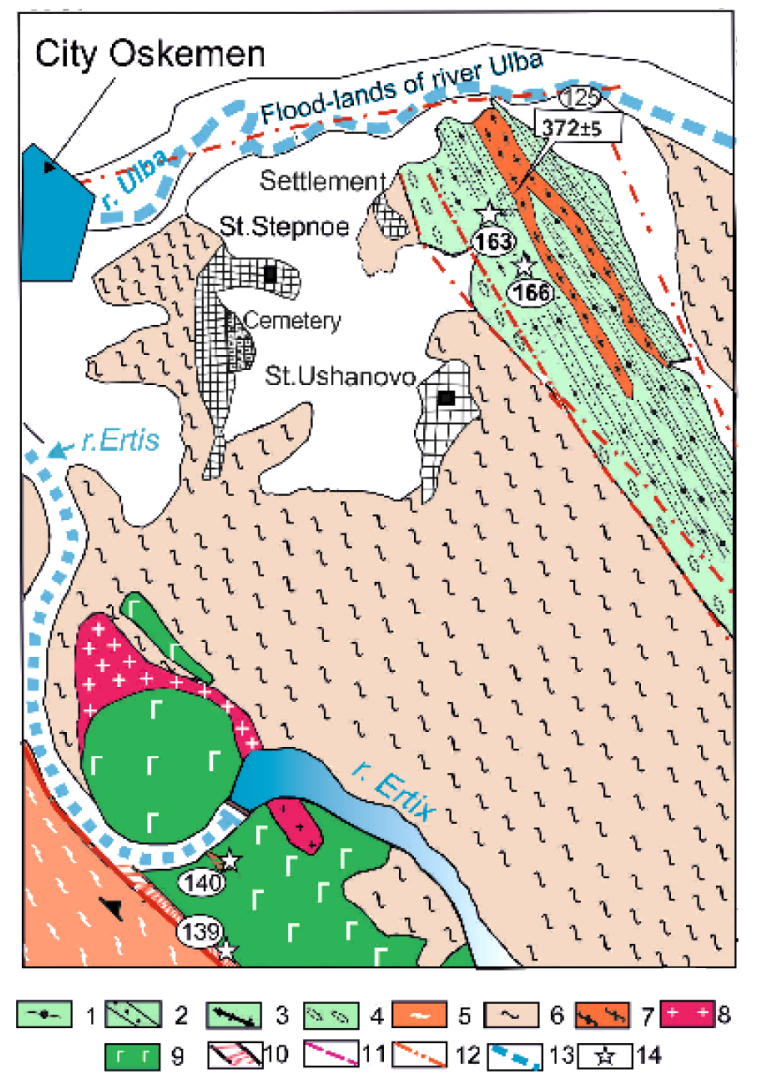

$a$

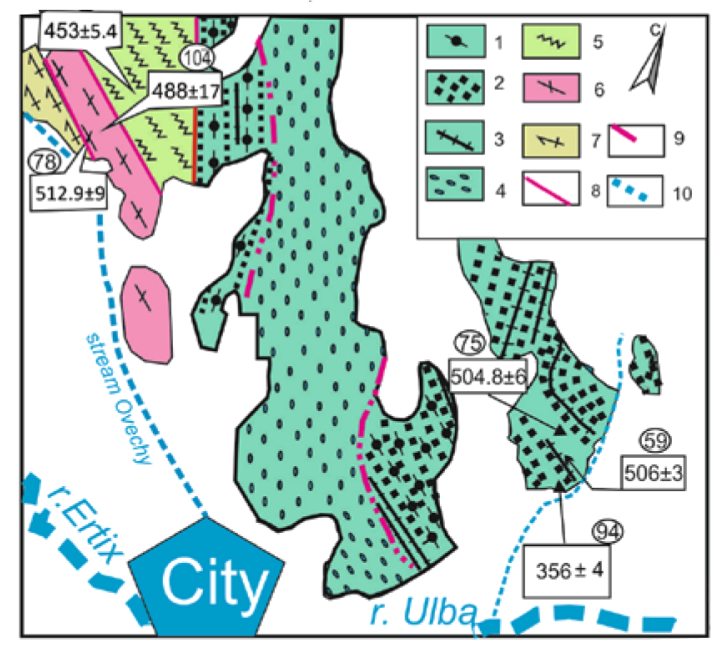

$b$

Fig. 1. Geological structure of the right and left banks of the Ulba River:

$a$ - the geological structure of the left bank of the Ulba River: 1 - undeformed migmatite-gneisses $\mathrm{E}_{2}-\mathrm{O}_{3} ; 2$ - the same, plagioclase-diopside crystalline schists $\mathrm{E}_{2}-\mathrm{O}_{3} ; 3$ - intra-layer migmatite-granites of problematic age; 4 - deformed and repeatedly boudinaged migmatite-gneisses; 5 - granite-cordierite gneisses $P z_{3} ; 6$ - greenschist complex $P z_{2}\left(\right.$ ?); 7 - gneiss granites $D_{3} ; 8$ dikes of the $N-$ W orientation of early Carbon; 9 - the same, sublatitude orientation; 10 - granites presumably $P_{1} ; 11$ - peridotitegabbro Talovskiy massif $S_{1} ; 12$ - apogreenschist contact hornfels of the Talovsky massif; 13 - tectonic boundaries; 14 - the proposed boundary of the Rudny Altai and the Irtysh shear zone; 15 - rivers, streams; 16 - important sampling points and samples mentioned in the text; $b$ - the geological structure of the right bank of the Ulba River: 1 - undeformed migmatite-gneisses $E_{2}-$ $\mathrm{O}_{3} ; 2$ - the same, plagioclase-diopside crystalline schists $\mathrm{E}_{2}-\mathrm{O}_{3} ; 3$ - intra-layer migmatite-granites of problematic age; 4 - repeatedly deformed migmatite-gneisses, presumably $D_{3}-P_{1} ; 5$ - flat crystalline schists of high pressures $O_{3} ; 6-$ gneiss-granites $E_{2}-$ $O_{1} ; 7$ - staurolite crystalline schists of unknown age; 8 - faults; 9 - boundaries of the zone of repeatedly deformed migmatite gneisses (4); 10 - rivers and streams

tures and the third one is the greenschist complex whose separate members have signs of low and high pressures. The first complex is traced along the northeastern flank of the zone throughout its extent, the second one is characteristic only of the northwestern part of the zone, and the third one is formed by the first two from the northeast and from the southwest along the boundaries of the Irtysh zone with the Rudny Altai and KalbaNarym zones, respectively.

The first complex is represented by gneisses, migmatite-gneisses, and low-pressure crystalline schists. In deformed rocks, massive inclusions, as a rule, granites and granite-gneisses of different composition, have the form of oblong boulders (boudins). Their dimensions vary from several meters to centimeters and even to millimeters. The matrix is represented by biotite (dominant), quartz, feldspar and granite.

The main mineral paragenesis of migmatites includes biotite $(\mathrm{Fe} / \mathrm{Fe}+\mathrm{Mg}=0.57)$, feldspars, quartz, sillimanite and granite $\left(\mathrm{Alm}_{0.62-0.66} ; \mathrm{Py}_{0.26-0.31}\right.$;
Spess $_{3.03-0 / 04} ;$ Gross $\left._{0.03-0.04}\right)$. The accessory minerals are represented by fibrolite, andalusite, and staurolite $\left(N_{g}=\right.$ $=1.748, N_{p}=1.735$ ), which indicates a partial secondary diaphthosis of these rocks under conditions of low-temperature steps in the amphibolite facies of metamorphism. At the same time, there are traces of the rock stay under conditions of high temperatures. The basis for this conclusion was granite, in which the pyrope content varied from 26 to $31 \%$ according to the data of many microprobe analyses. The upper limit of the pyrope content in granite of the amphibolite facies is in the range of $16-18 \%$, while the higher pyrope content is indicative of either conditions of granulite facies or separation from magmatic melt (P. V. Yermolov, A. E. Isoh, A. G. Vladimirov). Wide presence of granite with a high pyrope and zircon content of magmatic appearance in the gneisses studied has become the basis for classifying migmatite-gneisses as orthogneisses.

Plagioclase-diopside crystalline schists in the original undisturbed form are well naked in the south-west out- 


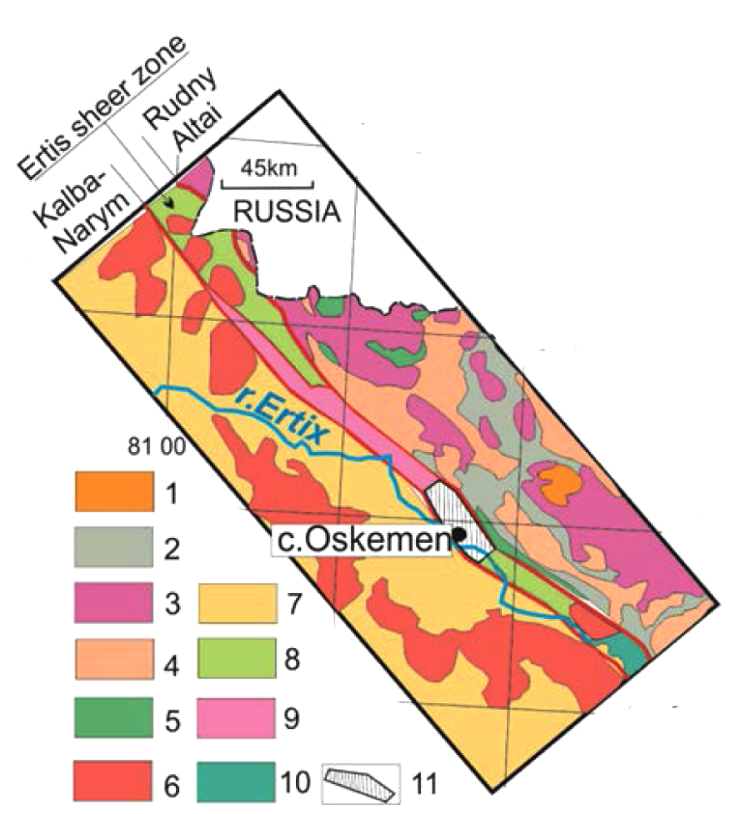

Fig. 2. Geological map of the Irtysh shear zone central part: 1-5 - the Rudny Altai structures: 1 - crystalline base of the Rudny Altai; 2 - Devonian structural floor; 3 - Carboniferous structural floor; 4 - granitoids of medium-late Carboniferous, undivided; 5 - late Paleozoic $\left(C_{3}-P_{1}\right) ; 6-$ Gremyachensky allochthon $P_{z_{1}}-C_{3} ; 7-8-$ structures of the Kalba-Narym terrain: 7 - coal sedimentary basin; $8-$ Kalbin batholith; 9-10 - structures of the Irtysh shear zone: 9 - crystalline schists and gneisses $\mathrm{E}_{2}-\mathrm{O}_{3} ; 10-$ greenschist complex $P z_{2}($ ?); 11 - area of the Irtysh shear zone studied in detail

skirts of Sogra village, where they form a monoclinically overlaying stratum. The occurrence of rocks as a whole is monoclinic. In-situ low-amplitude planar folds are characteristic. Stretching of the strata as a whole is north-west, the dip is steep, 80-90 degrees, mainly to the south-west.

The second complex of flattened shales and highpressure gneiss granites in the high-pressure metamorphic complex of the ISZ is mainly represented by siliceous-aluminous planar schists and granite-gneisses with characteristic paragenesis of granite + kyanite and monacyt + kyanite. They form a tectonic block. In the north, the block is covered by loose sediments, in the south it is bounded by a fault of the northeastern direction, lying under the river bed of the Ulba. On the left bank of this river there are no traces of the Sheep block, and the greenschist complex is widely developed there.

The basis of the third greenschist complex is calcareous albit-zpidot-actinolite crystalline schists; biotite and muscovite-chlorite crystalline schists have a subordinate distribution. The conditions of metamorphism correspond to the medium- and high-temperature subfacies of greenschist facies. The presence of garnet in some green shales suggests that some of their diafluorites are from more deeply metamorphosed crystalline schists.

The age of the rocks of the greenschist complex in most of the territory under consideration dates from the Middle Devonian on the basis of collections of fauna in limestones and the data of spore-pollen analysis in green shales. On the right bank of the Ulba River in the scales of green shales there were identified spore-pollen complexes $\mathrm{C}_{3}-\mathrm{P}_{1}$, and in green shales directly southeast of the territory under consideration, M.S.Kozlov found the Silurian fauna. In the scales of green shales on the right bank of the Ulba River located tectonically on the unmetamorphosed rocks of the Upper Paleozoic and characterized by the spore-pollen complex $\mathrm{C}_{3}-\mathrm{P}_{1}$ the Devonian microphytolites (the data of M. F. Mikunov) were also found. It is not improbable that its composition includes also the Lower Paleozoic formations.

The history of the development of the Irtysh shear zone in its studied segment has lasted more than 500 million years from the late Cambrian to the present. The Gneiss complex in this history is the most ancient. It consists of two layers: migmatite-gneiss and plagioclasediopside. The first one contains orthomagmatic migmatites (Fig. 1, $b$ ), which were formed from the silt diorites or dacites (Fig. 3, point 59). One of the bodies breaks through the diopside-plagioclase sequence, in which there are fully open contacts with the intrusive contact between the gneiss-migmatites and the diopside-plagioclase strata. Another feature has been established: zircon in morphology, age and composition in these rocks is the same, which allows considering these two strata as components of a single volcanic series in which diopsideplagioclase crystalline schists in the original form were calcareous tuffs and tuffites (Fig. 3, Zavaritsky). At point 59 migmatites are densely saturated with granite, the composition of which (the content of the pyrope component is $29-31 \%$ ) leads to magmatic temperatures of 850-900 ${ }^{\circ} \mathrm{C}$ [5], which agrees with the geological data.

The age of the gneiss complex is determined by the two concordias shown in Fig. 4.

Two centers with the ages of 506 and 505 million years corresponding to the formation time of the complex, and two centers with the ages of 463 and 422 million years corresponding to the metamorphic transformation time of the primary rocks, are distinguished on it. Two young centers with an age of 297 and 294 million years show the time of transformation of zircons during the Perm activation of the Irtysh zone. The period of time from metamorphism and approximately to the late Devon is a period of manifestation of viscous plastic deformations.

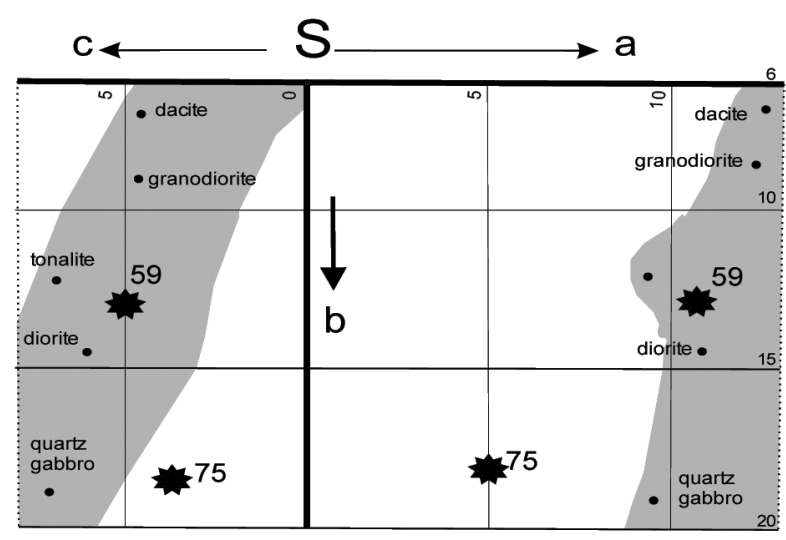

Fig. 3. Gneiss-migmatite (59) and diopside-plagioclase (75) rocks position in the Zavaritsky diagram (darkgrey background: the position of magmatic rock series) 

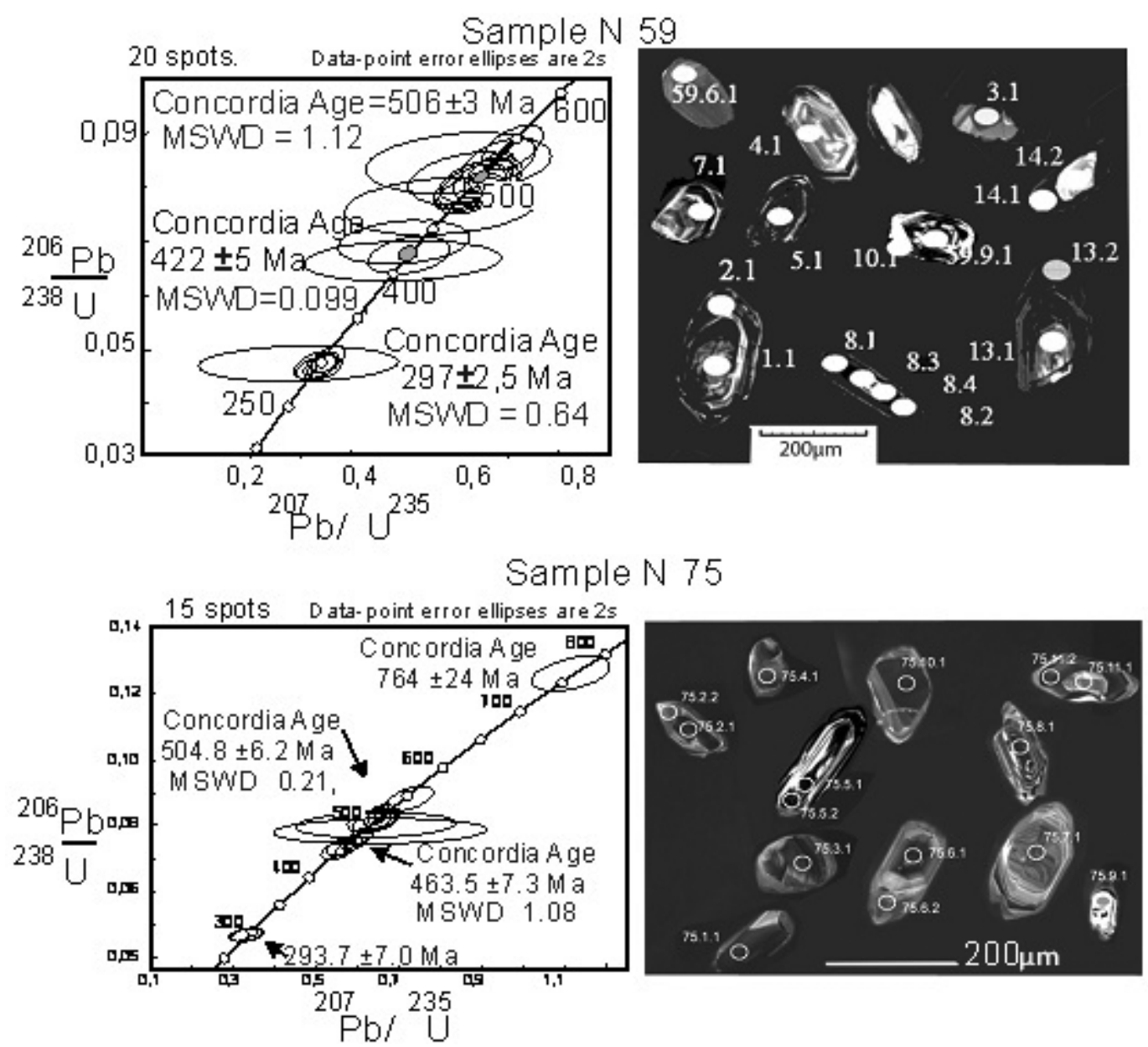

Fig. 4. High temperatures and mediate pressures crystalline rocks age in the Irtysh shear zone:

59 - orthomigmatite; 75 - plagioclase-diopside crystalline shale

The greenschist complex developed in the same mode, judging by the abundance of loamy structures. The Talovsky massif of gabbroids, which breaks it and is of an Early Carboniferous age, has very weak signs of deformation, indicating a large gap in time between the deformation of green shale and Early Carboniferous gabbroids

Similar flattened deformation structures are also characteristic of the low-temperature complex of high pressures, but the upper age boundary is not defined in it. All three complexes are combined into an accretionary package that was formed towards the end of the Devon or some time earlier. We consider the upper age boundary to be the intrusion of the Talovsky Massif and the bunch of northeastern dikes. This age, determined by four concordias (Fig. 5), corresponds to the early Carbonus 346-356 million years. In the time following, there dominated fragile-plastic (boudinage) and brittle (breccia) deformations in connection with left-sided and right-sided shear motions.

Conclusions and recommendations for further research.

1. The detailed geological, petrographic, and geochemical studies have made it possible to distinguish three independent metamorphic complexes: the one of high temperatures and moderate pressures (gneisses, migmatite gneisses, plagioclase-diopside crystalline schists), the one of low temperatures and high pressures (granite-kyanite planar schists and gneisses), and gneisses in which the facies of moderate pressures (layered shales) and high pressures (planar schists) are combined. Based on the five author's $\mathrm{U}-\mathrm{Pb}$ dating, the ages have been established: the first late Cambrian complex is the late Silur, the second one is the late Cambrian-Middle Ordovician. The Silurian age of the greenschist complex was established by previous researchers in the fauna.

2. The three above-mentioned complexes form an accretionary package of allochthonous integuments. The combination of this fact plus evidence of their early Paleozoic age made it possible to reject the previous model (Sengör, A. M.C., et al.) also of the accretionary origin, but of the Permian age, as well as the model of the autochthonous origin of the metamorphic complex (Travin A. V., Ponomarchuk V.A., Ponomareva A. P., et al.), formed by the Middle Paleozoic rocks due to collision processes in the Perm [7] (Melnikov A., et al.,). Based on the $\mathrm{U}-\mathrm{Pb}$ dating of dikes in the northeast strike crossing the gneiss-metamorphic complex, and the geological data of introducing the Talovsky Early Carboniferous massif into previously deformed green shales, we believe that accretion processes and formation 


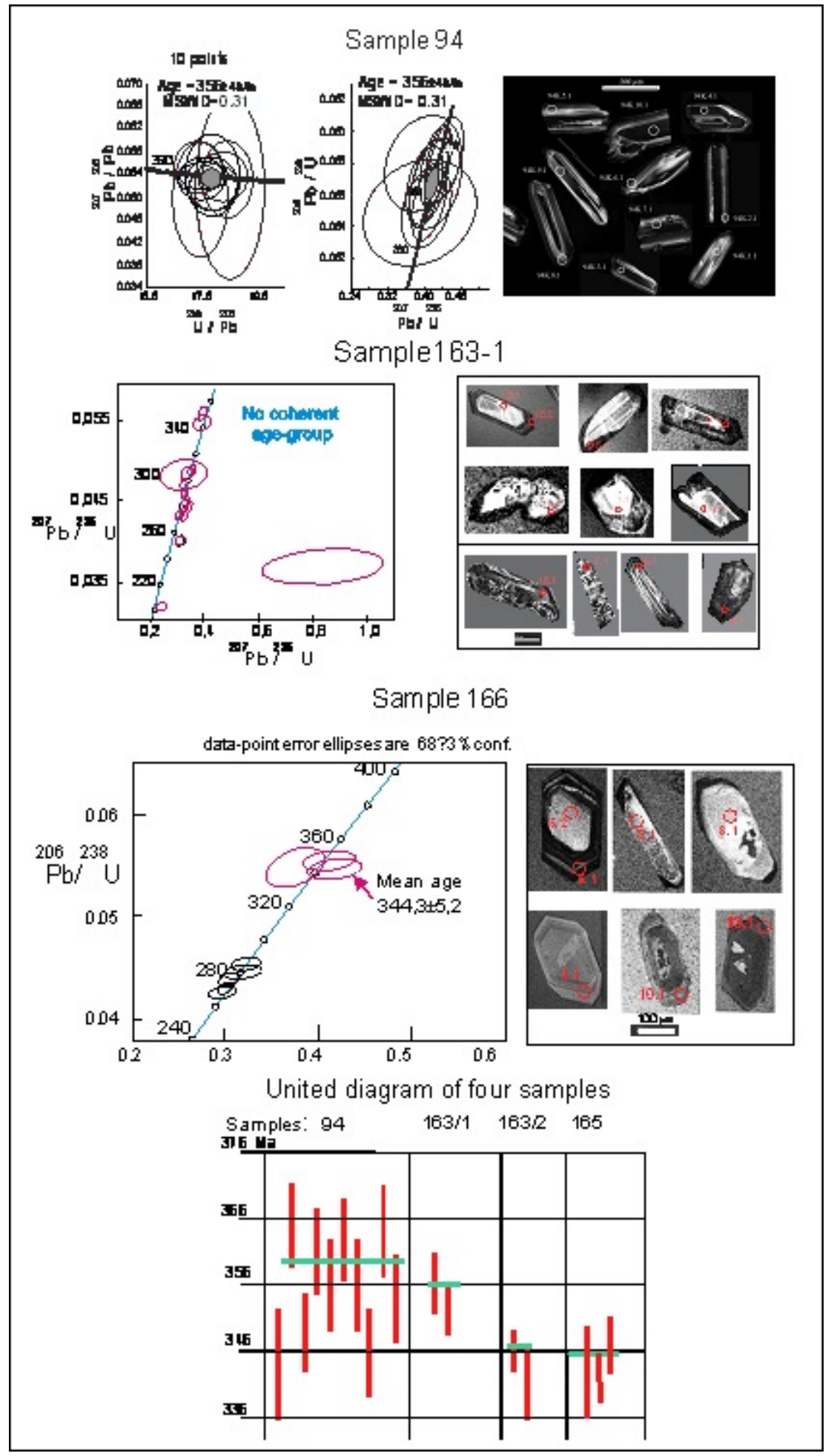

Fig. 5. Zircon concordias from the north-east dikes crossing the gneiss complex

of the Irtysh shear zone occurred in the late Silur - late Devon period. Subsequently, isotope dating indicates the activity in the Irtysh zone in early and late Perm, in Triassic and even in Yura, but these were exclusively shear deformations of the left- and right-sided plans.

\section{References.}

1. Briggs, S. M., Yin, A., Manning, C. E., Chen, Z. L., Wang, X. F. and Grove, M., 2007. Late Paleozoic tec- tonic history of the Ertix Fault in the Chinese Altai and its implications for the development of the Central Asian Orogenic System. Grove GSA Bulletin, Jily-August, 119(7/8), pp. 944-960. DOI: 10.1130/B26044.1.

2. Briggs, M.S., Yin, A., Manning, C.E., Chen, Z. L. and Wang, X.F., 2009. Tectonic development of the southern Chinese Altai range as determined by structural geology, thermobarometry, ${ }^{40} \mathrm{Ar} /{ }^{39} \mathrm{Ar}$ thermochronology, and Th/Pbiom-mcroprobe monazite geochro- 
nology. Geological Society of American Bulletin, 121, pp. 1381-1393. DOI: 10.1130/B26385.1.

3. Yermolov, P. V. and Polyansky, N. V., 2008. Main stages of tectonic development of the Irtysh shear zone: according to the data of isotope zircon analysis by the SHRIMP method. Geology and Protection of Mineral Resources [online], 3(28), pp. 17-24. Available at: <http://www.nauka. $\mathrm{kz} /$ page.php/upload/images/upload/files/prezentation_16092016_2.pptx?page_id=109\&lang $=1 \&$ page $=$ 2894 $>$ [Accessed 21 September 2017].

4. Zhang, C-L., Zou, H., Santosh, M. and Wang, H.-Y., 2012. Revisiting the Irtysh tectonic belt: Implications for the Paleozoic tectonic evolution of the Altai orogeny. Journal of Asian Earth Sciences, 52, pp. 117-133. DOI: 10.1016/j.jseaes. 2012.02.016.

5. Yermolov, P. V., 2013. Relevant problems of isotope geology and metallogeny in Kazakhstan. Karaganda: KRU. 6. Glorie, S., De Grave, J., Buslov, M. M., Zhimulev, F. I., Izmer, A., Elburg, M. A., Ryabinin, A. B., Vandoorne, W., Vanhaeke, F. and Van den Haute, P., 2011. Formation and Palaeozoic evolution of the Gorny-AltaiMongolia suture zone (South Siberia): zircon U/Pb constraints on the igneous record. Gondwana Research, 20, pp. 465-484. DOI: 10.1016\%2Fj.gr.2011.03.003.

7. Travin, A. V., Boven, A., Plotnikov, A. V., Vladimirov, V.G., Theunissen, K., Vladimirov, A.G., Melnikov, A. and Titov, A.V., 2001. Ar-40/Ar-39 dating of ductile deformations in the Irtysh shear zone, eastern Kazakhstan. Geochemistry International [online], 39(12), pp. 1237-1241. Available at: <https://www.researchgate. net/publication/293143563_40Ar39Ar_dating_of_ductile_deformation_in_the_Irtysh_shear_zone_Eastern_ Kazakhstan> [Accessed 4 November 2017].

\section{Вік і геодинаміка Іртишської зони зминання}

\section{П. В. Ермолов ${ }^{1}$, К. В. Пономарьова ${ }^{2}$, В. С. Портнов ${ }^{2}$}

1 - Інститут проблем комплексного освоєння надр, м. Караганда, Республіка Казахстан, e-mail: permolov@ipkon.kz 2 - Карагандинський державний технічний університет, м. Караганда, Республіка Казахстан, e-mail: sea_kitten_1@ mail.ru; vs_portnov@mail.ru

Мета. Вивчення вікових і структурних співвідношень Іртишської зони зминання з Калба-Наримською зоною, визначення віку й геодинамічної позиції кристалічних порід високих температур і помірних тисків Іртишської зони зминання.

Методика. Аналіз літературних і фондових матеріалів; проведення польових досліджень; пробопідготовка; виконання ізотопних досліджень за технологією SHRIMP-2 і LA-ICP-MS; визначення малих елементів методом сплавлення з використанням ICP.

Результати. Детальні геологічні, петрографічні й геохімічні дослідження дозволили виділити три самостійних метаморфічних комплекси Іртишської зони зминання, визначити їх вік і встановити геодинамічну позицію комплексів, що складають Ipтишську зону зминання.

Наукова новизна. Визначено вік найголовніших магматичних і метаморфічних комплексів, що розвинуті на центральній частині Іртишської зони зминання; використані технології SHRIMP-II, LAICP-MS зарубіжних лабораторій; на результатах нових датувань скоригована геодинаміка Іртишської зони зминання.

Практична значимість. Із позицій аккреційної тектоніки, з використанням сучасних методів ізотопного датування, здійснюється спроба розглянути геодинаміку геоблоків кори (,,террейнів“) і знайти продовження рудних рівнів і рудних поясів одних террейнів в інших.

Ключові слова: ізотопне датування, геодинамічна позиція, метаморфічні породи, граніто-гнейси, сланці, циркон, Іртишська зона зминання

\section{Возраст и геодинамика Иртышской зоны смятия}

\section{П. В. Ермолов ${ }^{1}$, Е. В. Пономарева ${ }^{2}$, В. С. Портнов ${ }^{2}$}

1 - Институт проблем комплексного освоения недр, г. Караганда, Республика Казахстан, e-mail: permolov@ipkon.kz 2 - Карагандинский государственный технический университет, г. Караганда, Республика Казахстан, е-таil: sea_kitten_1@mail.ru; vs_portnov@mail.ru

Цель. Изучение возрастных и структурных соотношений Иртышской зоны смятия с Калба-Нарымской зоной, определение возраста и геодинамической позиции кристаллических пород высоких температур и умеренных давлений Иртышской зоны смятия.

Методика. Анализ литературных и фондовых материалов; проведение полевых исследований; пробоподготовка; выполнение изотопных исследований по технологии SHRIMP-2 и LA-ICP-MS; определение малых элементов методом сплавления с использованием ICP.

Результаты. Детальные геологические, петрографические и геохимические исследования позволили выделить три самостоятельных метаморфических комплекса Иртышской зоны смятия, определить их возраст и установить геодинамическую позицию комплексов, слагающих Иртышскую зону смятия.

Научная новизна. Определен возраст главнейших магматических и метаморфических комплексов, развитых на центральной части Иртышской зоны смятия; использованы технологии SHRIMPII, LA-ICP-MS зарубежных лабораторий; на результатах новых датировок скорректирована геодинамика Иртышской зоны смятия.

Практическая значимость. С позиций аккреционной тектоники, с использованием современных методов изотопного датирования, предпринимается попытка рассмотреть геодинамику геоблоков коры (,террейнов“) и найти продолжение рудных уровней и рудных поясов одних террейнов в других.

Ключевые слова: изотопная датировка, геодинамическая позиция, метаморфические породы, гранито-гнейсы, сланцы, циркон, Иртышская зона смятия

Рекомендовано до публікації Т.В.Кряжевою. Дата надходження рукопису 23.10.17. 